$$
\frac{210 / 7^{2}}{H_{1} 2^{3} 3^{3}}
$$

BOND-ADHESION STUDY OF ELECTROLESS NICKEL PLATING ON TYPE 4340 STEEL

C. A. Reeves, Jr 


\section{DISCLAIMER}

This report was prepared as an account of work sponsored by an agency of the United States Government. Neither the United States Government nor any agency Thereof, nor any of their employees, makes any warranty, express or implied, or assumes any legal liability or responsibility for the accuracy, completeness, or usefulness of any information, apparatus, product, or process disclosed, or represents that its use would not infringe privately owned rights. Reference herein to any specific commercial product, process, or service by trade name, trademark, manufacturer, or otherwise does not necessarily constitute or imply its endorsement, recommendation, or favoring by the United States Government or any agency thereof. The views and opinions of authors expressed herein do not necessarily state or reflect those of the United States Government or any agency thereof. 


\section{DISCLAIMER}

Portions of this document may be illegible in electronic image products. Images are produced from the best available original document. 
Printed in the United States of America. Available from National Technical Information Service

U.S. Department of Commerce

5285 Port Royal Road, Springfield, Virginia 22151

Price: Printed Copy \$3.00; Microfiche $\$ 0.95$

This report was prepared as an account of work sponsored by the United States Government. Neither the United States nor the United States Atomic Energy Commission, nor any of their employees, nor any of their contractors, subcontractors, or their employees, makes any warranty, express or implied, or assumes any legal liability or responsibility for the accuracy, completeness or usefulness of any information, apparatus, product or process disclosed, or represents that its use would not infringe privately owned rights.

Reference to a company or product name does not imply approval or recommendation of the product by Union Carbide Corporation or the U S Atomic Energy Commission to the exclusion of others that may meet specifications. 


\title{
BOND-ADHESION STUDY OF ELECTROLESS NICKEL PLATING ON TYPE 4340 STEEL
}

\author{
C. A. Reeves, Jr
}

Oak Ridge Y-12 Plant

P.O. Box Y, Oak Ridge, Tennessee 37830

operated for the U.S. ATOMIC ENERGY COMMISSION bY UNION CARBIDE CORPORATION-NUCLEAR DIVISION under Contract W-7405-eng-26

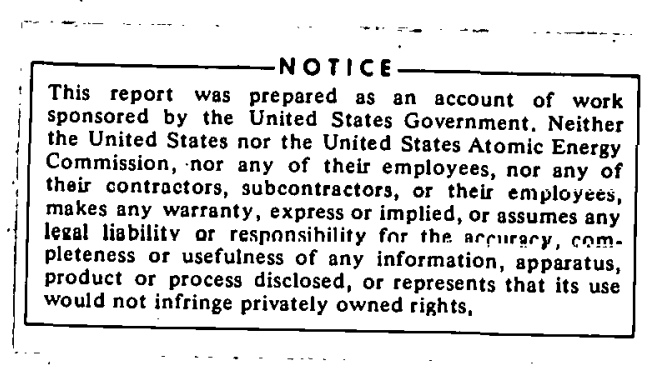

Date Issued -. November 8, 1972 
THIS PAGE

\section{WAS INTENTIONALLY \\ LEFT BLANK}


ABSTRACT

A study has been made of the adhesion strength of electroless nickel plating on Type 4340 steel. This study had a two-fold purpose: (1) to determine the optimum plating conditions, and $(2)$ to find a new test method to certify the bond strength. Specimens which had received a pretreatment by different procedures were plated in order to ascertain this effect on plating adhesion. Adhesion strength was determined by tensile testing these specimens and determining the relative plating adhesion from the total area of plating flake off and the average number of crazing lines per linear inch. The test method has proved to be satisfactory. 


\section{CONTENTS}

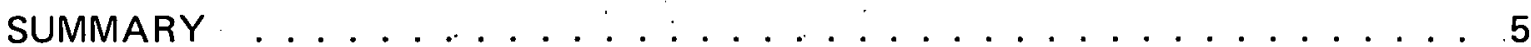

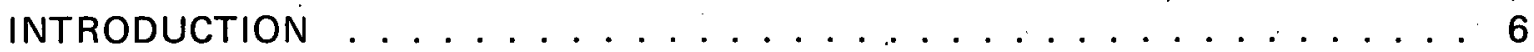

BOND ADHESION OF THE ELECTROLESS NICKEL PLATE . . . . . . . . . . 7

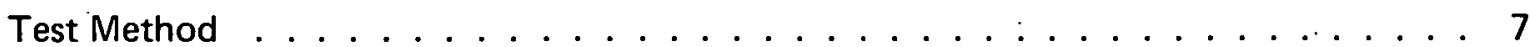

The Tensile Test . . . . . . . . . . . . . . . . . 7

Data Analysis . . . . . . . . . . . . . . . . . 8

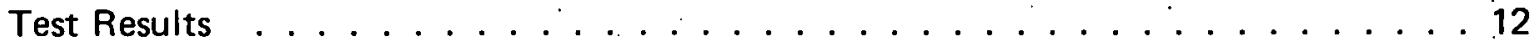

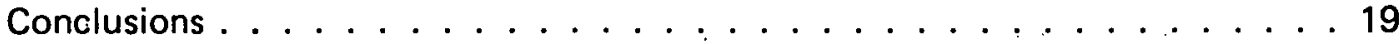




\section{SUMMARY}

This study was undertaken in order to develop, if possible, a new test method to certify the degree of adhesion of the electroless nickel plate on Type 4340 steel. A severe bend test has been performed in the past to certify this process step, but the results have proved to be difficult to interpret. At the same time it was desired to study the effects of various surface pretreatments on bond adhesion strength. The method involves testing a standard tensile specimen to a predetermined strain level and measuring the total area of plating flake off and the number of crazing lines per linear inch. (a)

This test has proved to be capable of discriminating between surface treatments, specifically between surfaces with no pretreatment (via vapor blasting) and those with some sort of. pretreatment. The main discriminator has turned out to be the number of crazing lines and not the total area of flake off, a difference that has been more than adequate to provide significant discrimination. The pretreated specimens showed essentially no deep crazing lines, while the untreated ones showed an average of 70 to 85 lines per linear inch. Each group seemed to show a difference in their flake-off area, but the scatter of data was so large in most cases that this difference could not be shown to be statistically significant.

(a) The testing method has been entitled the CAR (crazing average rate) testing method. 


\section{INTRODUCTION}

In the past, the Oak Ridge $\mathrm{Y}-12$ Plant $^{(\mathrm{b})}$ has certified the plating adhesion strength of the nickel plating on Type 4340 steel by performing a 180-degree bend test. During this test, the specimens that had been plated with the parts were usually broken. The certification method was then one of estimating the degree of plate flaking from the specimen to determine if it met the established criteria. Since the specimen was almost always broken, there was usually extensive flaking around the break region, making it very difficult to obtain a meaningful interpretation.

In an attempt to avoid problems of this type, a new test method was devised whereby a standard tensile specimen was plated with the Type 4340 steel part in the same manner as the bend-test coupon had been plated, then this specimen was tested on a universal testing machine to a total strain of approximately four percent. The total plating flake-off area was then measured; as well as the number of crazing lines that appeared during testing. These two results were then used to certify the quality of the plating adhesion, thus eliminating most of the interpretation problems which arose in the former method.

Concurrent with establishing the improved testing method, a study was performed to determine that the method was sensitive enough to differentiate between those parts that had failed to receive a vapor-blasting treatment prior to plating and those that had received the proper pretreatment. (It was felt that failure to receive a proper pretreatment was one of the major causes for an inadequate plate adhesion.) Also, it was desired to find out what effect surface treatments by various grits of vapor-blast compound and various surface treatments before and after plating would have on plate adhesion on the 16 and $32 \mathrm{rms}$ seal surfaces of the part.

Chemical analyses of the plating on the tensile specimens were also performed in order to determine their phosphorus content, and to attempt to correlate these analyses with the quality of the plating adhesion. However, the results of these analyses were too scattered to be of any value.

(b) Operated by the Union Carbide Corporation's Nuclear Division for the US Atomic Energy Commission. 


\section{BOND ADHESION OF THE ELECTROLESS NICKEL PLATE}

\section{TEST METHOD}

\section{The Tensile Test}

A standard flat tensile specimen was utilized for routine laboratory testing for material certification and characterization. Specifications for this specimen agree with those established by $\mathrm{Y}-12$ for rectangular tensile specimens of a one-inch gage length. Figure 1 gives the essential features of the test specimen.

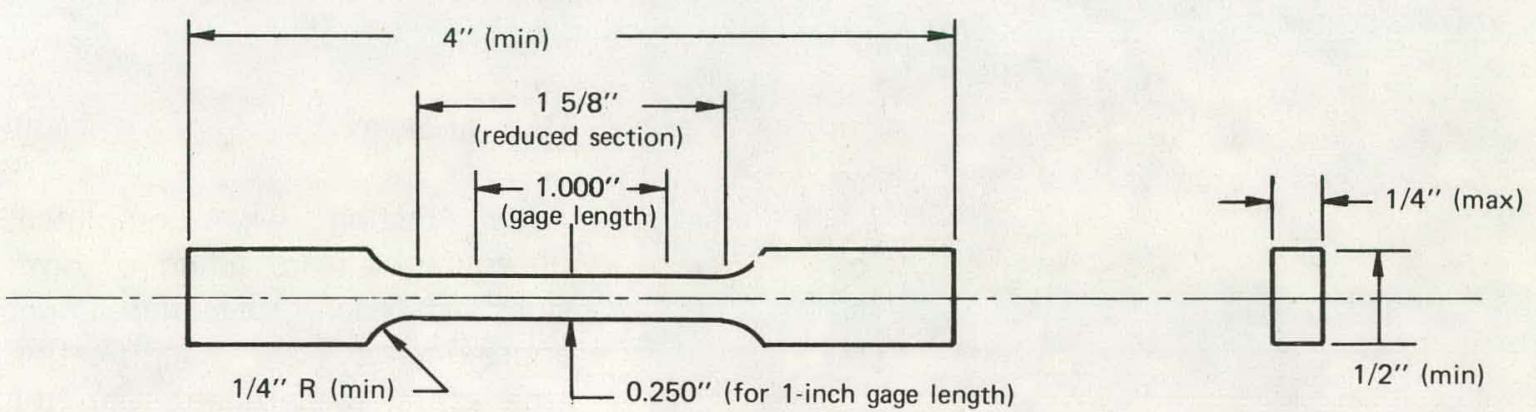

Figure 1. FLAT TENSILE TEST SPECIMEN.

The specimen actually used was a slight modification of the design shown in Figure 1. This modification was incorporated in the design solely to make plating easier. The specimen meets all requirements of ASTM Test Method E-8.

Specimens were fabricated from material that was identical to that used in the Type 4340 steel parts which they represented. The material was sampled prior to plating for its mechanical properties, and the coupons were inspected for surface finish to ascertain that all were identical to that used for the parts.

After this study was completed it was realized that some of the problems that had been encountered while trying to grip the ends of the specimens could be remedied by removing the plating from the ends of the specimens by vapor blasting down to within $1 / 4$ of an inch of the radius on each end. This treatment allowed the grips to obtain an adequate "bite" into the specimen, a problem which had appeared earlier.

The specimens were tested in ordinary wedge-action tensile test jaws in a 30,000-pound, electromatic, screw-driven Tinius-Olsen testing machine at a uniform crosshead-motion rate of $0.05 \mathrm{in} / \mathrm{min}$. Strain was measured via a one-inch LVDT-type extensometer mounted to the specimen, as depicted in Figure 2.

The specimens were pulled in tension at the chosen crosshead speed until either a total of four percent strain had been measured by the extensometer or until the load being applied showed a marked decrease. This latter condition would indicate an undesirable imminent failure of the specimen substrate. A load-versus-strain plot was obtained automatically. An example of such a plot is given in Figure 3. A load range of $0-6,000$ pounds and a strain 


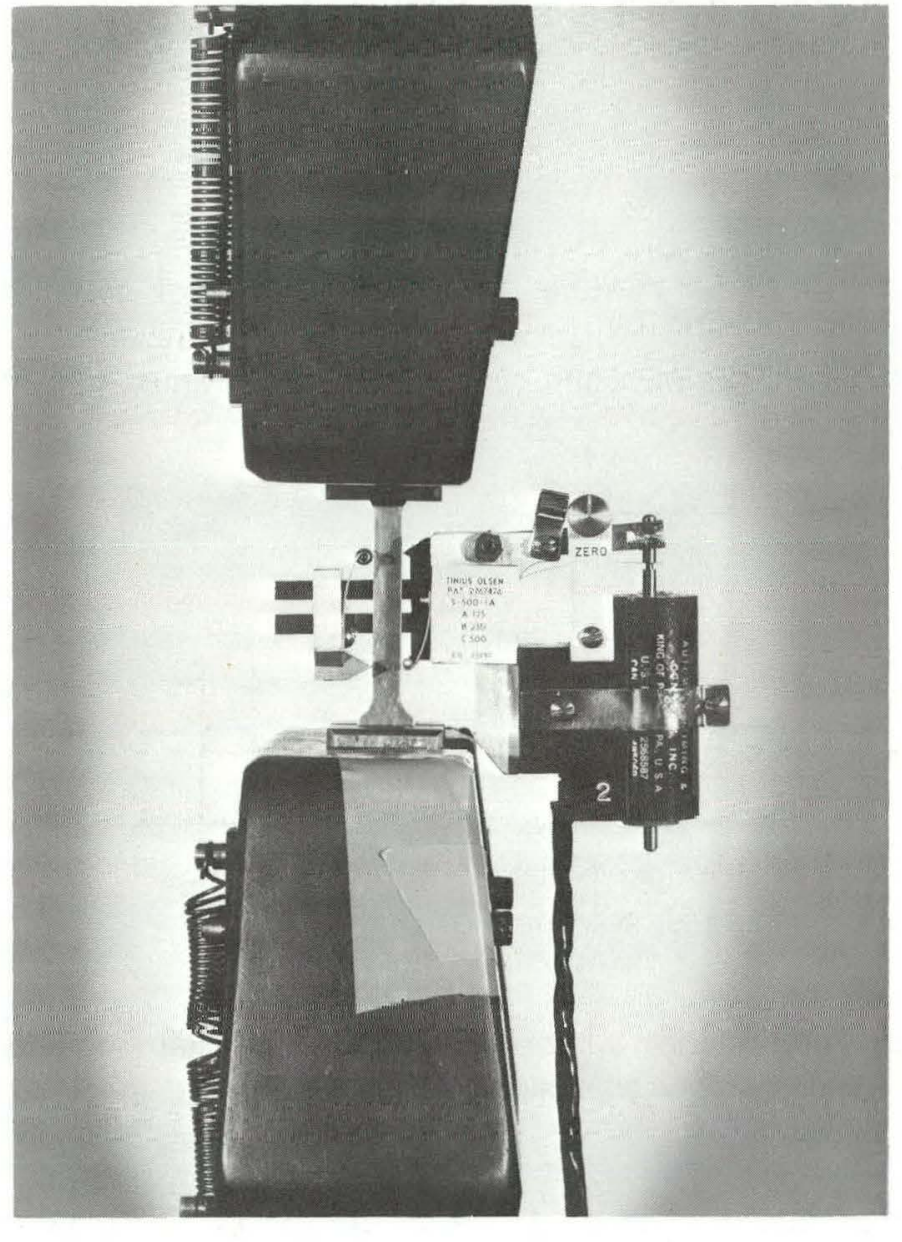

144090

Figure 2. TYPICAL TEST SPECIMEN WITH AN EXTENSOMETER.

runge of $00.080 \mathrm{in} / \mathrm{in}(0-8 \%)$ were used for most of tlięses lessls.

After testing, the speriment was removed from the tensile testing machine and any loose plating was removed by forcibly picking at the louse edyes of the plate wlth a tungsten carbide pick or scriber. The plating flakes were then sel aside for further measurement.

\section{Data Analysis}

After testing was completed, photographs were taken of both sides of each specimen under approximately $2 \mathrm{X}$ magnification (the actual magnification on the photographs was 2.4X). These photographs were then analyzed by twn ter.hniruss: (1) measuring the total area of plating flake off on both sides wilhin a prescribed area, and (2) counting the number of crazing lines on both sides of the specimen and determining the average number per linear inch.

Both of these measurements were performed within a. rectangular area which omitted the edges and ends of the specimens from analysis. The edges were omitted because it was felt that the type of flaking which normally occurred in this region was not representative of the type of failure which would occur in the part; the ends were omitted because this region was gripped by the jaws in testing, and flaking occurred there due to jaw "biting". A photograph showing a typical analysis area is presented in Figure 4. In practice, a rectangle was drawn on a sheet of clear plastic and this became an overlay for the photographs. Thus, the same rectangle was used for analyzing all photographs. This procedure should have avoided any variance in the data due to analysis-area variations.

Measurement of the average number of crazing lines was straightforward in that all that was done was to count the total number of lines within the rectangle for each side of the specimen, and average the two values. In practice, only those lines contained in a length of about $1 / 4$ inch of this rectangular area were counted, since quite a large amount of the plating had flaked off the area under analysis on some of the specimens. The numbers obtained were then corrected to account for both the flaking and magnification of the photograph. 


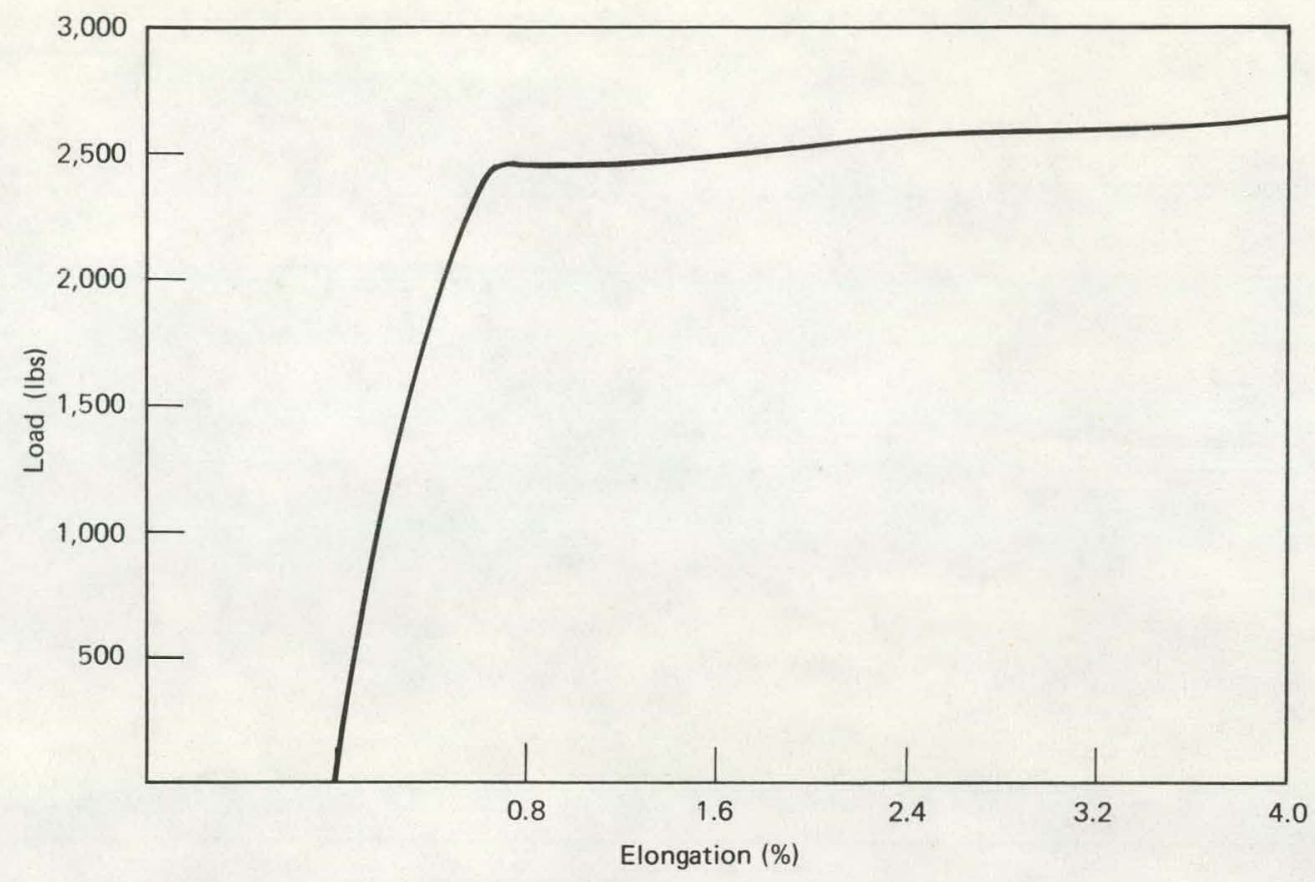

Figure 3. A TYPICAL LOAD-VERSUS-STRAIN PLOT.

Total area of plating flake off was also measured from these photographs. All measurements were made on a Hewlett-Packard Model 9100A programmable calculator and Model 9107A digitizer, as seen in Figure 5.

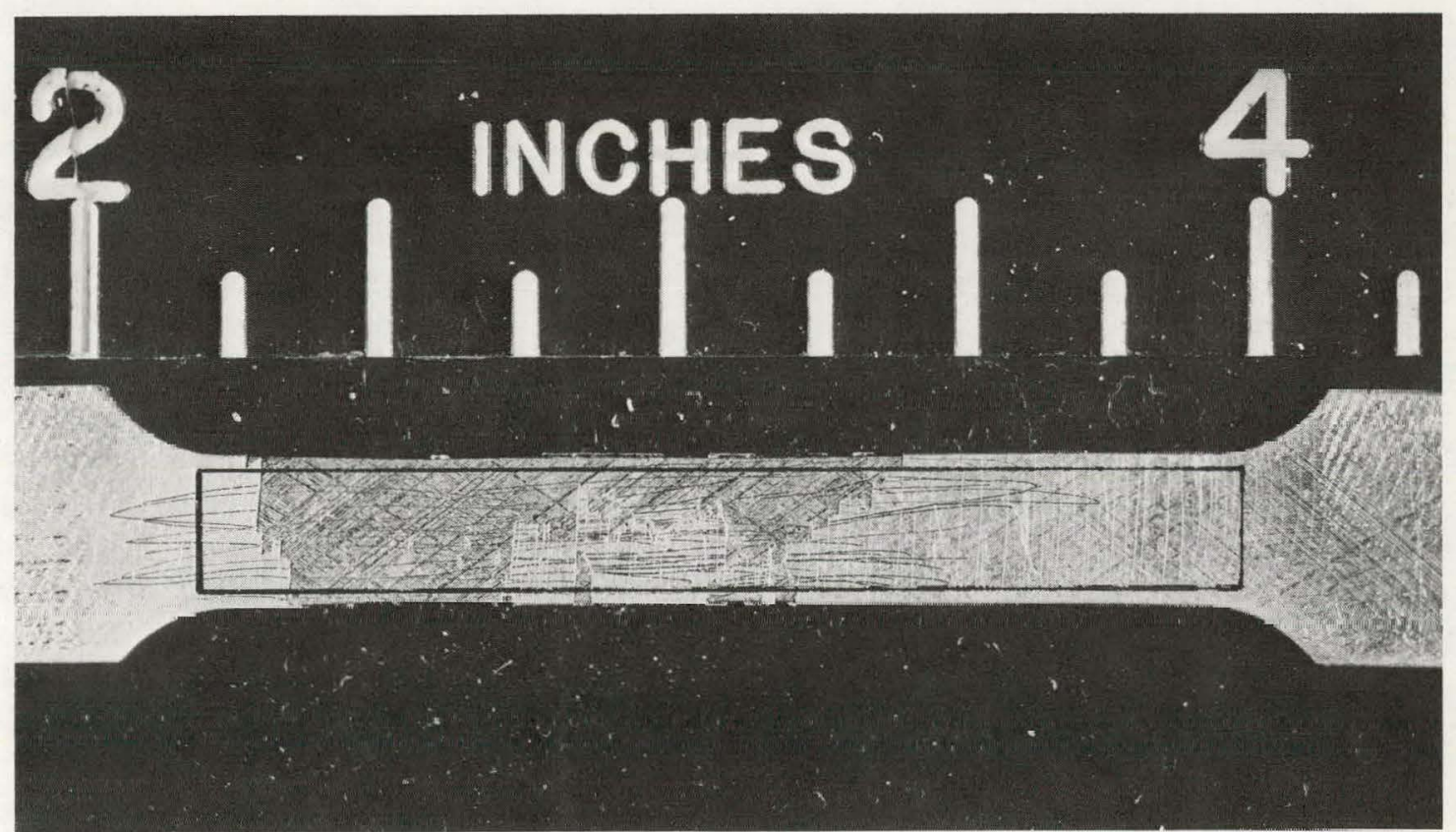

Figure 1. A TYPICAL ANALYSIS AREA. (Note Rectangular Overlay) 


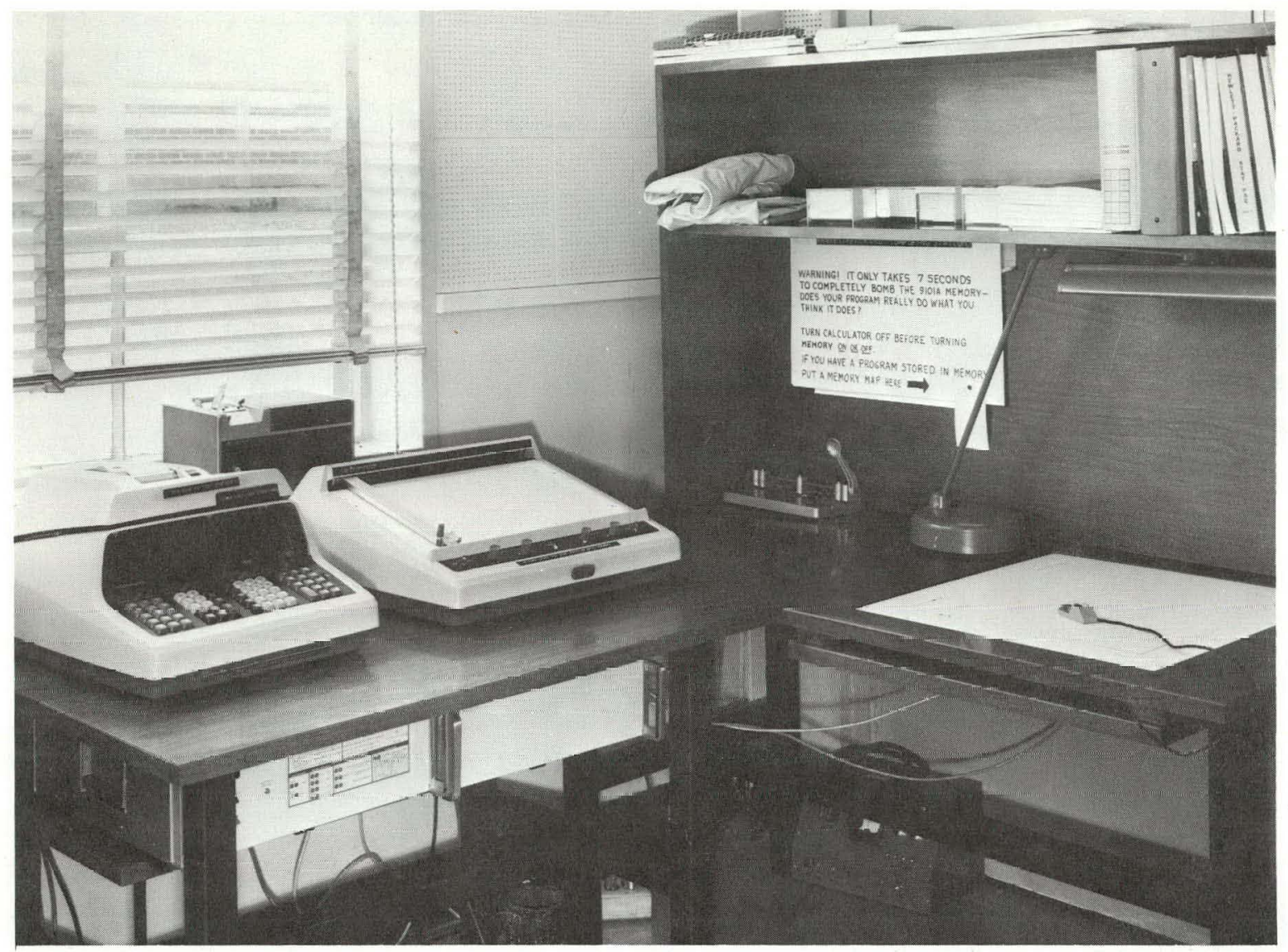

144092

Figure 5. CALCULATOR SYSTEM USED FOR THE FLAKING MEASUREMENTS. (Calculator on the Left; Digitizer on the Right)

The purpose of the digitizer is to provide $X-Y$ cartesian-type coordinates of any point on the digitizer surface, referenced to any other point chosen by the operator. Once the points of a given curve are digitized in this manner, the calculator is then used to perform calculations on these points. A calculator program was furnished with the digitizer which would calculate areas enclosed within the digitized curve, and this program was used for all these measurements. The method utilized is the so-called "trapezoidal" method whereby areas of trapezoids formed by the data points are calculated and summed over the entire area. The size of the trapezoid, and hence the accuracy of the results, is determined by the sampling rate, which is believed to have been high enough to yield reasonably accurate data. The areas of each flaked-off portion on each side of each specimen were measured and these were totaled for the desired result. Corrections to account for the magnification of the photographs were also made.

One problem, which would tend to add variance to the area results, did become evident in the study. An example of the problem is indicated in Figure 6. The area of plate flaking near the end is believed to be due, primarily, to either misalignment of the specimen in the grips or by incorrect machining of the specimens. Results from specimens machined in this 


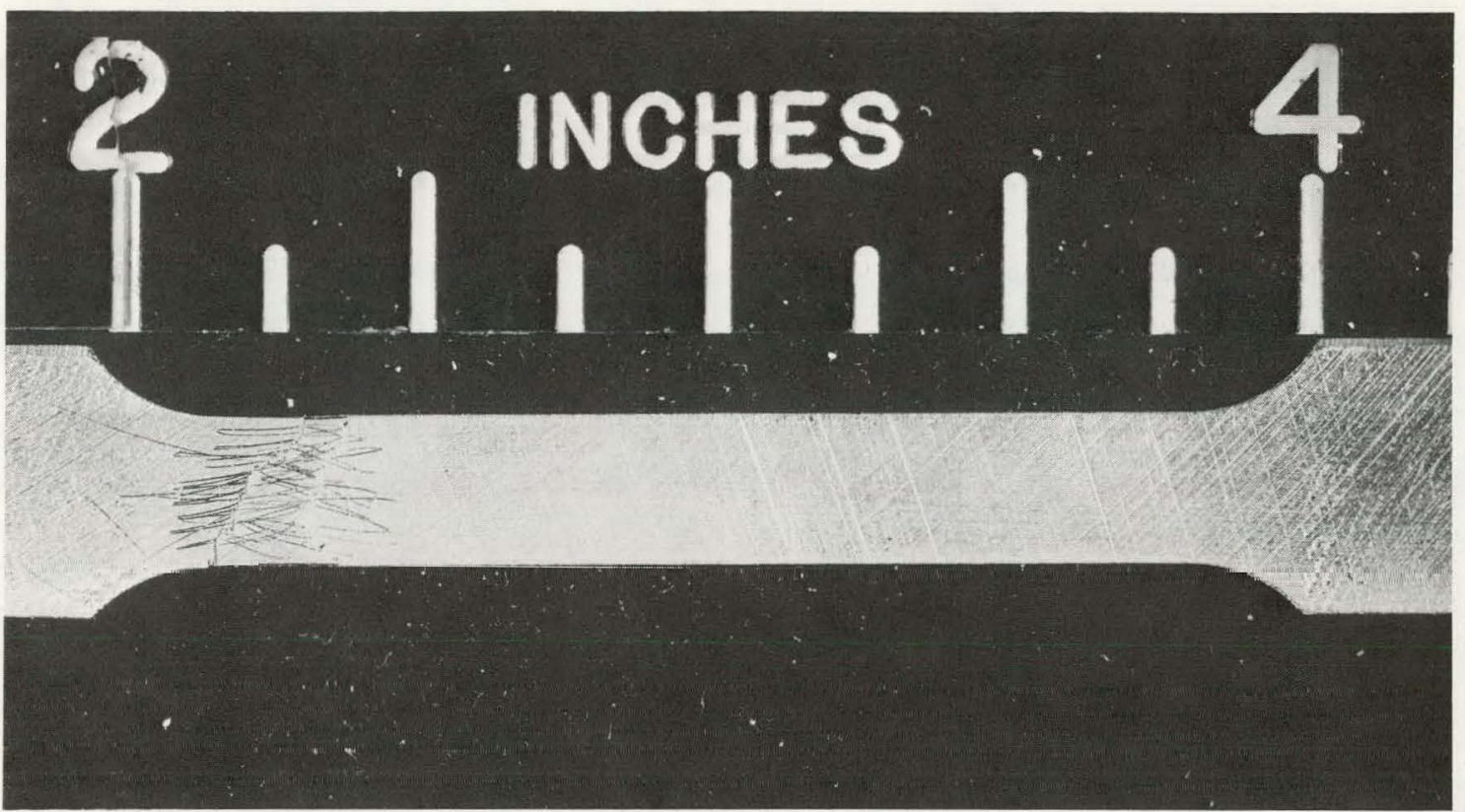

Figure 6. AN EXAMPLE OF FLAKING DUE TO MISALIGNMENT.

MS-71-0907-13

manner were not included in the summary of test results which follows. Two steps were taken to correct this problem in certification testing:

1. Dimensional inspection of specimens prior to plating.

2. Use of a small plexiglass fixture, illustrated in Figure 7 , as a setup fixture to aid in alignment. The purpose of the fixture is to control the perpendicularity of the specimen relative to the grip face.

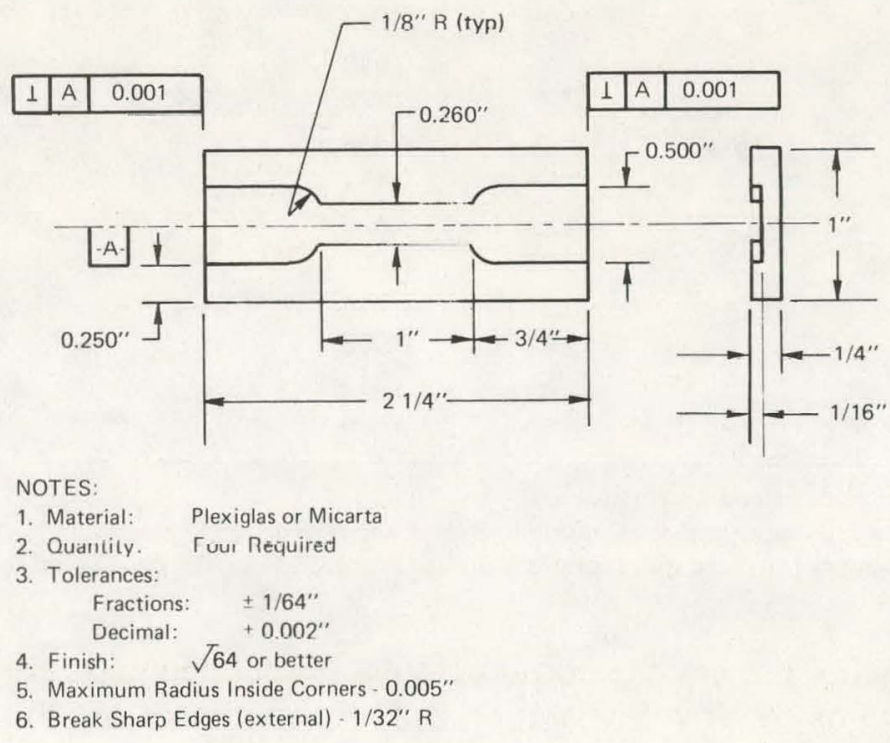

Figure 7. SPECIMEN HOLDER. 


\section{TEST RESULTS}

Summarized in Table 1 are the results obtained from the test program by applying the methods described earlier. The surface preparation conditions studied were:

1. No pretreatment at all. Specimen surfaces were studied as they were in the as-machined condition.

2. Specimen surfaces were vapor blasted with 150-grit silicon oxide prior to plating.

3. Specimen surfaces were vapor blasted with 325-grit silicon oxide prior to plating.

4. Specimen surfaces were polished to a 16-microinch finish or better before vapor blasting with 325-grit silicon oxide prior to plating.

5. Specimen surfaces were polished as in Preparation 4, then vapor blasted with 150-grit silicon oxide prior to plating.

6. Specimen surfaces were polished as in Preparation 4, then vapor blasted with 400-grit aluminum oxide prior to plating.

Table 1

SUMMARY OF TEST RESULTS FOR SPECIMENS TREATED PRIOR TO PLATING

\begin{tabular}{|c|c|c|c|c|c|c|c|}
\hline \multirow{2}{*}{$\begin{array}{c}\text { Surface } \\
\text { Preparation }(1)\end{array}$} & \multirow{2}{*}{$\begin{array}{c}\text { Bath } \\
\text { Type (2) }\end{array}$} & \multirow{2}{*}{$\begin{array}{l}\text { Average } \\
\text { Plating } \\
\text { Thickness } \\
\text { (mils) }\end{array}$} & \multirow{2}{*}{$\begin{array}{c}\text { Average } \\
\text { Total } \\
\text { Percent } \\
\text { Elongation }\end{array}$} & \multirow{2}{*}{$\begin{array}{c}\text { Average } \\
\text { Total } \\
\text { Flake } \\
\text { Area } \\
\left(\text { in }^{2}\right)\end{array}$} & \multirow{2}{*}{$\begin{array}{c}\text { Average } \\
\text { Number of } \\
\text { Crazing } \\
\text { Lines } \\
\text { Per Inch (3) }\end{array}$} & \multicolumn{2}{|c|}{$\begin{array}{c}\text { Average Surface } \\
\text { Finish ( } \mu \text { in) }\end{array}$} \\
\hline & & & & & & Before Plating & After Plating \\
\hline \multirow[t]{2}{*}{1} & 1 & 4.3 & 3.41 & 0.087 & 85.4 & 57.0 & 40.8 \\
\hline & 2 & 3.5 & 3.54 & 0.023 & 69.6 & 59.8 & 38.3 \\
\hline \multirow[t]{2}{*}{2} & 1 & 3.9 & 3.50 & 0.042 & 1.3 & 44.2 & 47.7 \\
\hline & 2 & 4.2 & 3.78 & 0.023 & 2.4 & 43.5 & 39.5 \\
\hline \multirow[t]{2}{*}{3} & 1 & 3.8 & 3.55 & 0.036 & - & 49.3 & 59.3 \\
\hline & 2 & 3.3 & 2.64 & 0.111 & - & 47.9 & 65.3 \\
\hline \multirow[t]{2}{*}{4} & 1 & 3.1 & 3.39 & 0.069 & - & 7.4 & 15.9 \\
\hline & 2 & 1.6 & 3.97 & 0.001 & - & 7.5 & 22.7 \\
\hline \multirow[t]{2}{*}{5} & 1 & 3.4 & 3.51 & 0.016 & - & 27.5 & 24.2 \\
\hline & 2 & 3.8 & 3.84 & 0.028 & - & 28.1 & 22.2 \\
\hline \multirow[t]{2}{*}{6} & 1 & 3.7 & 3.48 & 0.020 & - & 7.6 & 8.3 \\
\hline & 2 & 3.9 & 3.80 & 0.096 & - & 8.3 & 8.4 \\
\hline
\end{tabular}

(1) Preparation condition as described on this page.

(2) Bath 1 - fresh bath; Bath 2 - same bath after group in Bath 1 had been plated.

(3) "Deep" lines only. Number for those that received a surface preparation can be considered to be zero.

The specimens which represent the current regular production parts are being vapor blasted with 150-grit silicon oxide, as in Preparation 2. These specimens and those from Preparation 1 were the most important of the groups as far as this analysis is concerned, for it is between these two groups that a definite discrimination was evident. 
Along with data pertaining to the average total flake area and the average number of crazing lines per linear inch, data concerning the average plating thickness as measured with a micrometer, the average percent elongation which the specimens experienced, and the average surface finish before and after plating are also reported in Table 1. Data are given for two sets of specimens for each condition, one set being plated in a fresh bath (Bath 1) and the second being plated in that same bath after the first group had been completed (Bath 2).

Measurement of "deep" crazing lines in the plating (meaning those which extended through to the substrate) were performed on the first two groups only. As noted, the first group (no vapor blasting) was the only one which showed deep lines of any consequence; those not reported on other groups can be considered to be essentially zero.

As can be seen from these data, some difference can be noted between groups with regard to their total flake areas; but, as will be shown later, these differences are, in most cases, not statistically significant. However, the crazing-lines measurements show a marked difference between the first two groups, and it is upon this basis that the discrimination can be made. The actual data from which these averages were computed are presented in Table 2. Data may have been omitted from this table and the resultant analysis for one of the following reasons:

1. The specimen may have ruptured in test.

2. The major flaking area was near one end, indicating specimen misalignment.

3. Some specimens were tested before an absolute test method had been devised.

4. Specimen slipped in the gripping devices, resulting in considerably less than four percent total elongation.

Also reported are the averages along with " $S$ " values (estimate of the standard deviation) for each.

The values reported for the average surface finishes and plating thicknesses are those for the entire specimen group, including those omitted for the reasons previously listed.

It should be obvious from these data that little correlation exists between any of the following items:

1. Percent elongation versus fläke area.

2. Bath 1 versus Bath 2 flake areas, in most cases.

3. Finish before or after plating versus flake area.

4. Any of the last four surface treatments versus each other.

However, drastic differences can be noted between the first two groups with regard to the number of crazing lines; and, to some extent, with regard to the area of flaking. Differences 
Table 2

DETAILED DATA FROM SPECIMEN TESTTS

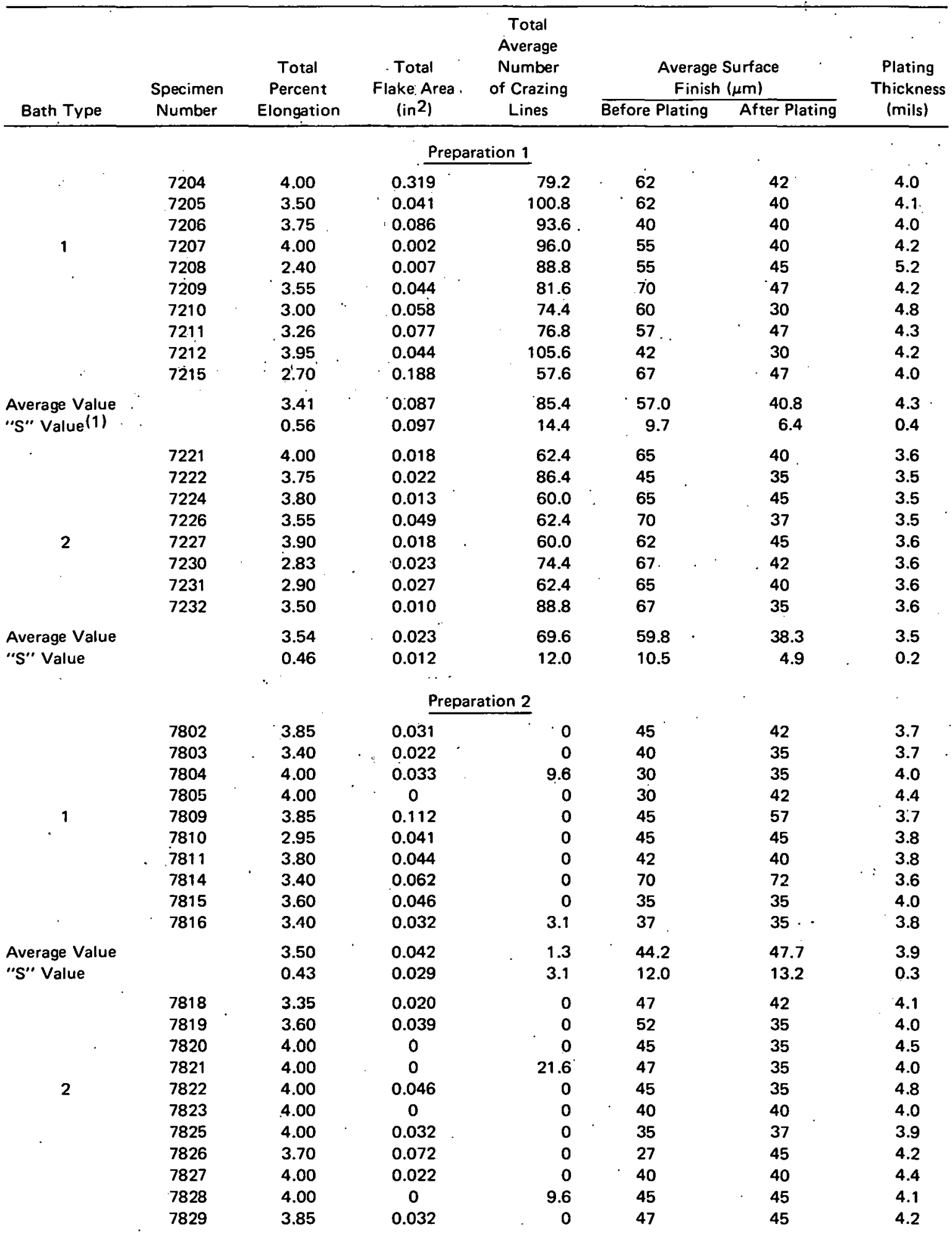

(1) Estimate of the standard deviation. 
Table 2 (Continued)

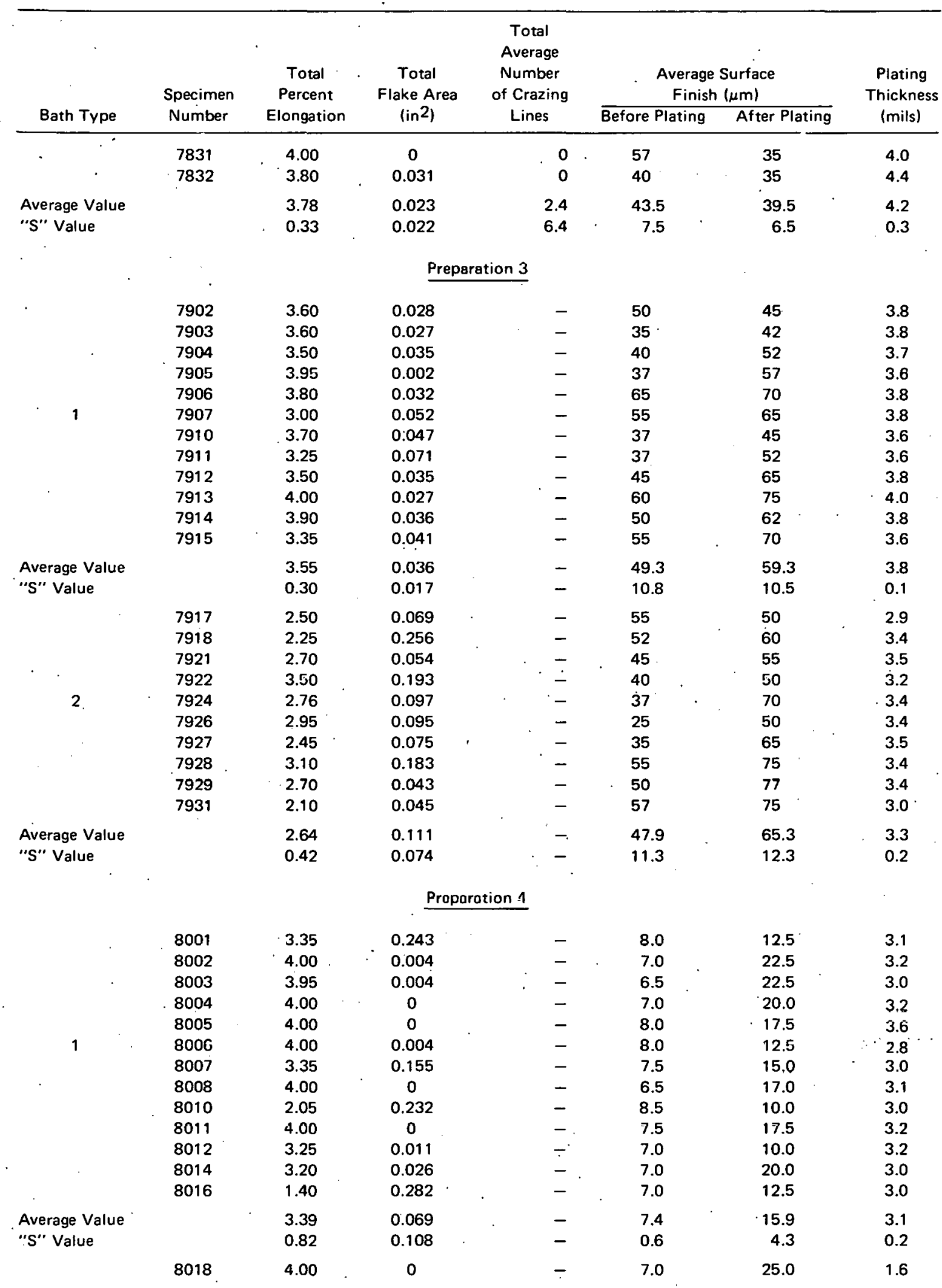


Table 2 (Continued)

\begin{tabular}{|c|c|c|c|c|c|c|c|c|}
\hline \multirow{2}{*}{ Bath Type } & \multirow{2}{*}{$\begin{array}{l}\text { Specimen } \\
\text { Number }\end{array}$} & \multirow{2}{*}{$\begin{array}{c}\text { Total } \\
\text { Percent } \\
\text { Elongation. }\end{array}$} & \multirow{2}{*}{$\begin{array}{c}\text { Total } \\
\text { Flake Area } \\
\text { (in 2) }\end{array}$} & \multirow{2}{*}{\multicolumn{2}{|c|}{$\begin{array}{c}\text { Total } \\
\text { Average } \\
\text { Number } \\
\text { of Crazing } \\
\text { Lines }\end{array}$}} & \multicolumn{2}{|c|}{$\begin{array}{c}\text { Average Surface } \\
\text { Finish }(\mu \mathrm{m}) \\
\end{array}$} & \multirow{2}{*}{$\begin{array}{c}\text { Plating } \\
\text { Thickness } \\
\text { (mils) }\end{array}$} \\
\hline & & & & & & Before Plating & After Plating & \\
\hline & 8019 & 4.00 & 0 & & - & 7.0 & 22.0 & 1.6 \\
\hline & 8020 & 4.00 & 0 & & - & 7.0 & 20.0 & $1.6^{\circ}$ \\
\hline & 8021 & 4.00 & 0 & & - & 7.5 & 24.0 & 1.6 \\
\hline · & 8022 & 4.00 & 0 & & - & 9.0 & 19.0 & 1.6 \\
\hline \multirow[t]{4}{*}{2} & 8023 & 4.00 & 0 & & - & 8.5 & 21.0 & 1.6 \\
\hline & 8024 & 4.00 & 0 & & - & 8.0 & 24.0 & 1.6 \\
\hline & 8025 & 4.00 & 0 & & - & 7.5 & 25.0 & 1.6 \\
\hline & 8026 & 4.00 & 0.008 & & - & 8.0 & 25.0 & 1.5 \\
\hline \multirow[t]{6}{*}{$\cdot$} & 8027 & 4.00 & 0.007 & & - & 8.0 & 22.0 & 1.6 \\
\hline & 8028 & 4.00 & 0 & & - & 7.0 & 20.0 & 1.5 \\
\hline & 8029 & 4.00 & 0.001 & & - & 7.0 & 25.0 & 1.6 \\
\hline & 8030 & 4.00 & 0 & . & - & 7.0 & 20.0 & 1.6 \\
\hline & 8031 & 3.70 & 0 & & - & 7.0 & 24.0 & 1.6 \\
\hline & 8032 & 3.90 & 0 & & - & 7.0 & 25.0 & 1.6 \\
\hline Average Value & & 3.97 & 0.001 & & - & 7.5 & 22.7 & 1.6 \\
\hline \multirow[t]{5}{*}{ "S" Value } & & 0.08 & 0.003 & & - & 0.7 & 2.2 & 0.04 \\
\hline & & & Prep & ation 5 & & $:$ & $\cdot$ & \\
\hline & 8502 & 4.00 & 0.009 & & - & 26 & 22 & 3.1 \\
\hline & 8503 & 3.40 & 0.041 & & - & 26 & 24 & 3.2 \\
\hline & 8505 & 3.80 & 0.028 & & - & 29 & 19 & 3.2 \\
\hline \multirow[t]{6}{*}{1} & 8506 & 4.00 & 0 & & - & 27 & 20 & 3.5 \\
\hline & 8507 & 3.30 & 0 & & - & 26 & 45 & 3.7 \\
\hline & 8512 & 4.00 & $\mathbf{0}$ & & - & 30 & 22 & 3.4 \\
\hline & 8513 & 3.95 & 0.026 & & - & 27 & 20 & 3.4 \\
\hline & 8514 & 3.00 & 0.040 & & - & 26 & 23 & 3.2 \\
\hline & 8515 & 4.00 & 0 & & - & 27 & 25 & 3.4 \\
\hline \multirow{6}{*}{$\begin{array}{l}\text { Average Value } \\
\text { "S" Value }\end{array}$} & & 3.51 & 0.016 & & - & 27.5 & 24.2 & 3.35 \\
\hline & & 0.53 & 0.018 & & - & 1.6 & . $\quad 7.0$ & 0.18 \\
\hline & 8519 & 4.00 & 0 & & - & 28 & 21 & 3.6 \\
\hline & 8520 & 3.98 & 0.047 & & - & 28 & 24 & 3.8 \\
\hline & 8521 & 3.90 & 0.058 & & - & 26 & 24 & 3.8 \\
\hline & 8522 & 3.65 & 0.034 & : & - & $30^{\circ}$ & 19 & 3.7 \\
\hline \multirow[t]{6}{*}{2} & 8525 & 4.00 & 0.019 & & - & 30 & 24 & 3.6 \\
\hline & 8526 & 4.00 & 0.016 & & - & 27 & 24 & 4.0 \\
\hline & 8527 & 4.00 & 0 & & - & 24 & 23 & 3.8 \\
\hline & 8528 & 4.00 & 0.002 & & - & 29 . & 21 & 3.8 \\
\hline & 8530 & 3.80 & 0.102 & & - & 27 & 25 & 3.7 \\
\hline & 8532 & 4.00 & 0.001 & & - & 30 & 22 & 3.8 \\
\hline Average Value & . & 3.84 & 0.028 & & - & 28.1 . & 22.2 & 3.8 \\
\hline \multirow[t]{4}{*}{ "S" Value } & & 0.22 & 0.033 & & - & 2.4 & 1.8 & 0.12 \\
\hline & \multicolumn{7}{|c|}{ Preparation 6} & \\
\hline & 9101 & 1.60 & 0 & & - & 10.0 & 9.0 & 3.8 \\
\hline & 9102 & 4.00 & 0.086 & & - & 8.0 & 7.5 & 3.7 \\
\hline \multirow[t]{5}{*}{1} & 9103 & 3.20 & 0.099 & & - & 6.0 & 9.0 & 3.6 \\
\hline & 9104 & 4.00 & 0.001 & & - & 7.5 & 8.0 & 3.8 \\
\hline & 9105 & 3.90 & 0.015 & & - & 8.0 & 7.5 & 3.6 \\
\hline & 9106 & 2.00 & 0.008 & & - & 10.5 & 7.0 & 3.5 \\
\hline & 9108 & 3.90 & 0 & . & - & 7.5 & 8.0 & 3.6 \\
\hline
\end{tabular}


Table 2 (Continued)

\begin{tabular}{|c|c|c|c|c|c|c|c|}
\hline \multirow[b]{2}{*}{ Bath Type } & \multirow{2}{*}{$\begin{array}{l}\text { Specimen } \\
\text { Number }\end{array}$} & \multirow{2}{*}{$\begin{array}{c}\text { Total } \\
\text { Percent } \\
\text { Elongation }\end{array}$} & \multirow{2}{*}{$\begin{array}{l}\text { Total } \\
\text { Flake Area } \\
\text { (in } 2)\end{array}$} & \multirow[t]{2}{*}{$\begin{array}{c}\text { Total } \\
\text { Average } \\
\text { Number } \\
\text { of Crazing } \\
\text { Lines }\end{array}$} & \multicolumn{2}{|c|}{$\begin{array}{c}\text { Average Surface } \\
\text { Finish }(\mu \mathrm{m}) \\
\end{array}$} & \multirow{2}{*}{$\begin{array}{l}\text { Plating } \\
\text { Thickness } \\
\text { (mils) }\end{array}$} \\
\hline & & & & & Before Plating & After Plating & \\
\hline & 9109 & 4.00 & 0.002 & - & 6.5 & 10.0 & 3.8 \\
\hline & 9110 & 4.00 & 0.009 & - & 7.0 & 7.5 & 4.0 \\
\hline & 9111 & 4.00 & 0 & - & 7.0 & 9.5 & 3.6 \\
\hline & 9112 & 3.00 & 0.032 & - & 7.0 & 9.0 & 3.7 \\
\hline & 9113 & 4.00 & 0 & - & 5.0 & 7.5 & 3.6 \\
\hline & 9114 & 4.00 & 0 & - & 9.0 & 9.0 & 3.8 \\
\hline & 9115 & 4.00 & 0.002 & - & 8.0 & 8.5 & 3.9 \\
\hline Average Value & & 3.48 & 0.020 & - & 7.6 & 8.3 & 3.7 \\
\hline \multirow[t]{8}{*}{ "S" Value } & & 0.82 & 0.032 & - & 1.4 & 0.9 & 0.14 \\
\hline & 9117 & 3.50 & 0.114 & - & 10.0 & 7.5 & 4.0 \\
\hline & 9118 & 3.20 & 0.052 & - & 10.0 & 8.0 & 4.0 \\
\hline & 9119 & 3.90 & 0.025 & - & 9.5 & 9.5 & 4.0 \\
\hline & 9120 & 4.00 & 0 & - & 9.0 & 8.0 & 4.0 \\
\hline & 9121 & 4.00 & 0.376 & - & 8.0 & 8.0 & 3.8 \\
\hline & 9122 & 4.00 & 0 & - & 7.5 & 9.5 & 4.0 \\
\hline & 9123 & 3.90 & 0.072 & - & 9.5 & 8.0 & 3.7 \\
\hline \multirow[t]{9}{*}{2} & 9124 & 4.00 & 0.037 & - & 7.0 & 9.5 & 3.8 \\
\hline & 9125 & 4.00 & 0.044 & - & 8.0 & 8.0 & 4.0 \\
\hline & 9126 & 3.75 & 0.184 & - & 8.0 & 8.5 & 3.8 \\
\hline & 9127 & 3.80 & 0.068 & - & 7.5 & 9.0 & 4.0 \\
\hline & 9128 & 3.80 & 0.189 & - & 8.5 & 9.5 & 3.8 \\
\hline & 9129 & 4.00 & 0.048 & - & 8.0 & 8.0 & 3.8 \\
\hline & 9130 & 4.00 & 0.270 & - & 7.0 & 9.0 & 3.8 \\
\hline & 9131 & 3.10 & 0.049 & - & 7.5 & 7.5 & 3.6 \\
\hline & 9132 & 4.00 & 0.004 & - & 8.0 & 7.5 & 3.8 \\
\hline Average Value & & 3.80 & 0.096 & - & 8.3 & 8.4 & 3.8 \\
\hline "S" Value & & 0.31 & 0.107 & - & 1.0 & 0.8 & 0.13 \\
\hline
\end{tabular}

seem to exist between baths concerning the averages of the plating area; but, in light of the large variance in data, these differences turn out to be statistically insignificant.

Figure 8 presents a photograph, at two magnifications, of a typical specimen from the first group of specimens (no pretreatment), showing the flaked area and the crazing lines. The crazing lines are shown in greater detail in View b, which is a further enlargement of View a. Easily visible in View $b$ are several lines which penetrate the entire layers of plating, and seem to be points at which plating flaking propagation is about to begin. The lines, running diagonally with the specimen width, are machine tool markings and are not to be confused with the flaking lines.

Following this study, certification levels were established for both the number of allowable crazing lines and the total permissible area of plating flake off. A view of typical good and bad specimens is given in Figure 9; enlargements of the views are seen in Figures 10 through 17. 


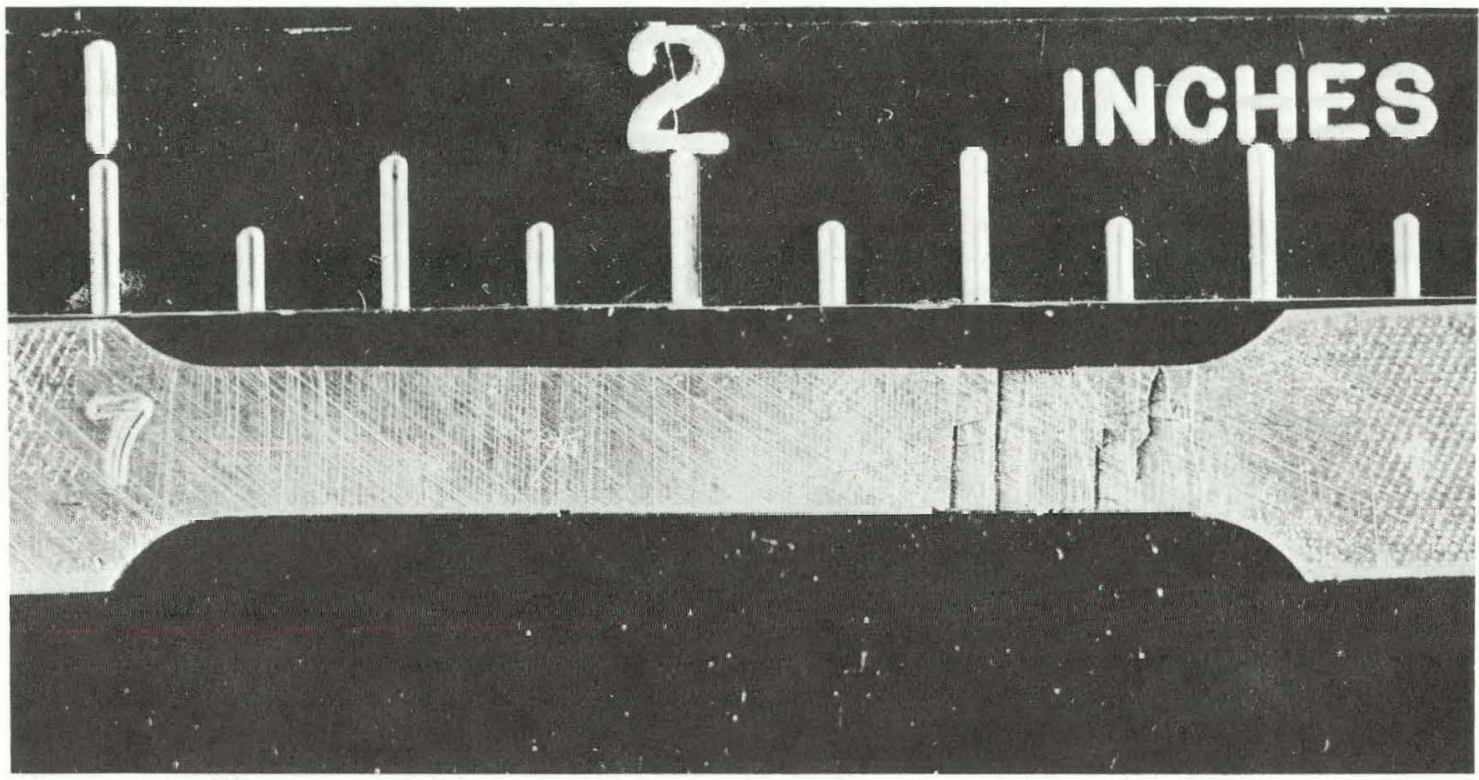

(a) At $2 X$

MS-71-0859-4

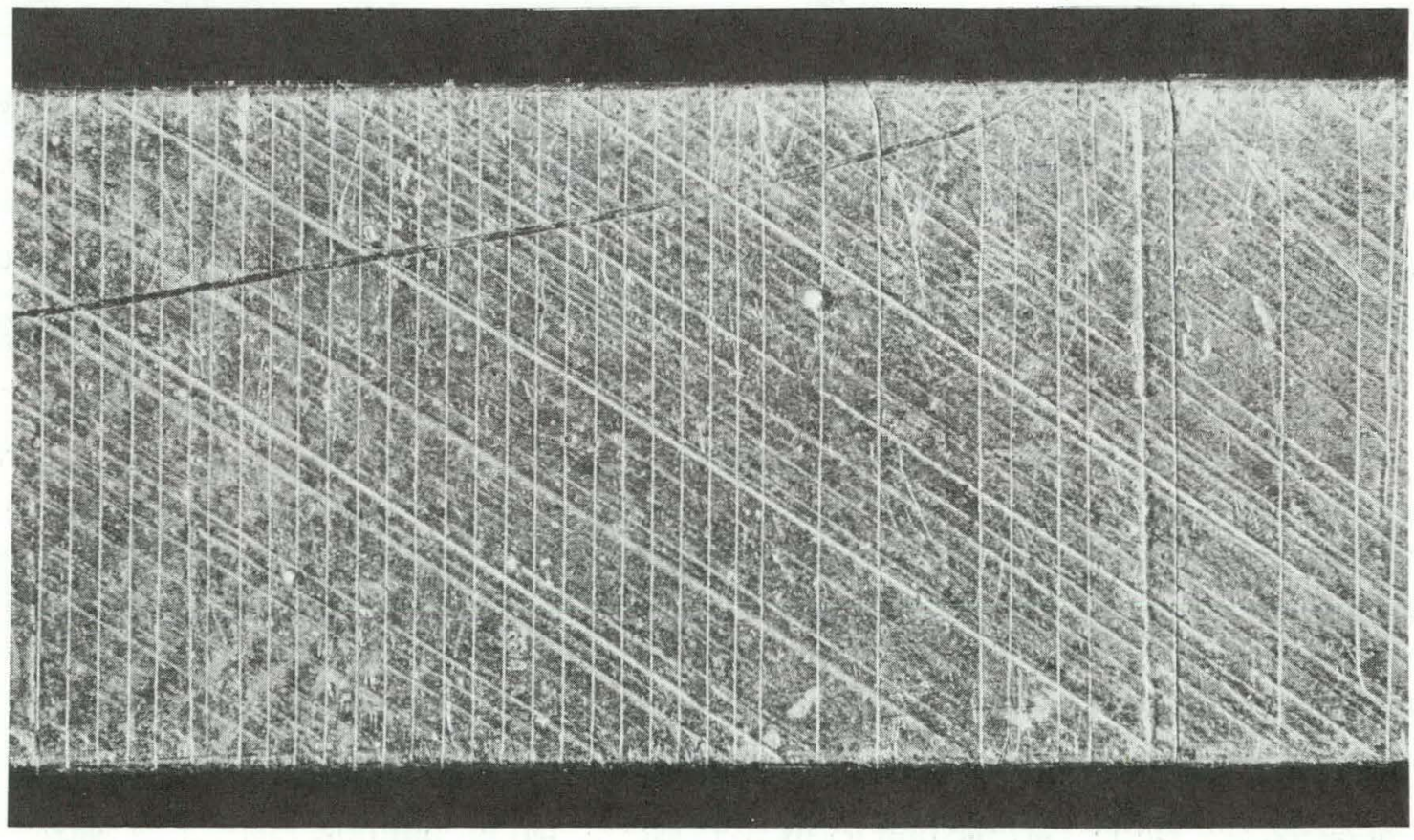

(b) At 10X

MS-71-0859-6

Figure 8. A TYPICAL SPECIMEN WHICH HAD RECEIVED NO PRETREATMENT. (Preparation 1, Page 12) 


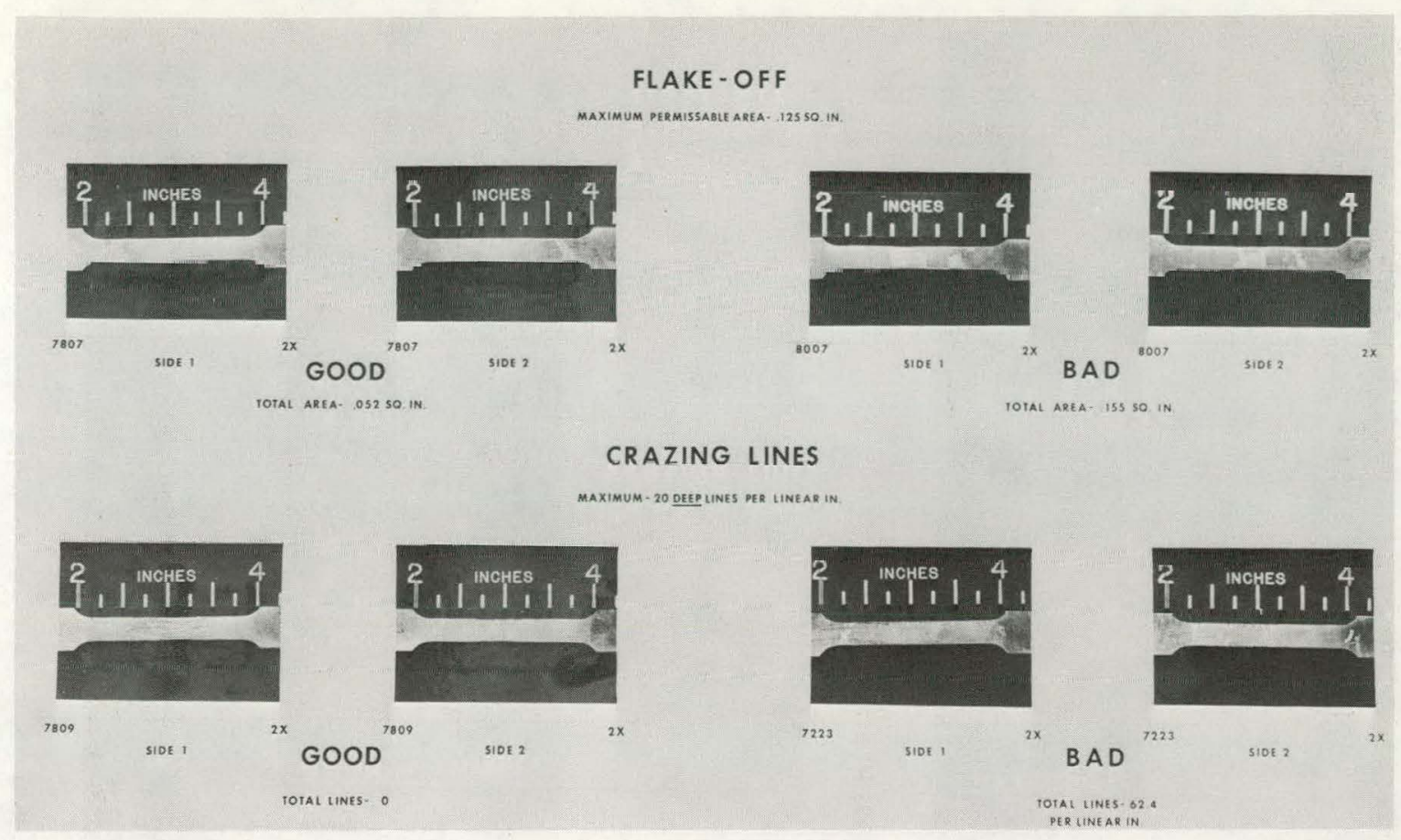

Figure 9. GUIDE FOR CERTIFYING THE TEST RESULTS.

144086

\section{Conclusions}

Statistically, the following statements may be made pertaining to the data presented in Tables 1 and 2.

\section{Total Flake Area -}

1. There is no significant difference between baths.

2. No surface preparation of the specimens (no vapor blasting) produces a higher flake area, but not significantly greater than the other groups due to the aforementioned large variance.

3. There is no apparent difference between the other groups.

\section{Surface Finish after Plating -}

1. There is no apparent difference between Baths 1 and 2 .

2. Significant differences do exist between the surface preparation treatments as they affect the surface finish. The treatments seem to fall into four groups with no significant differences within those groups. 


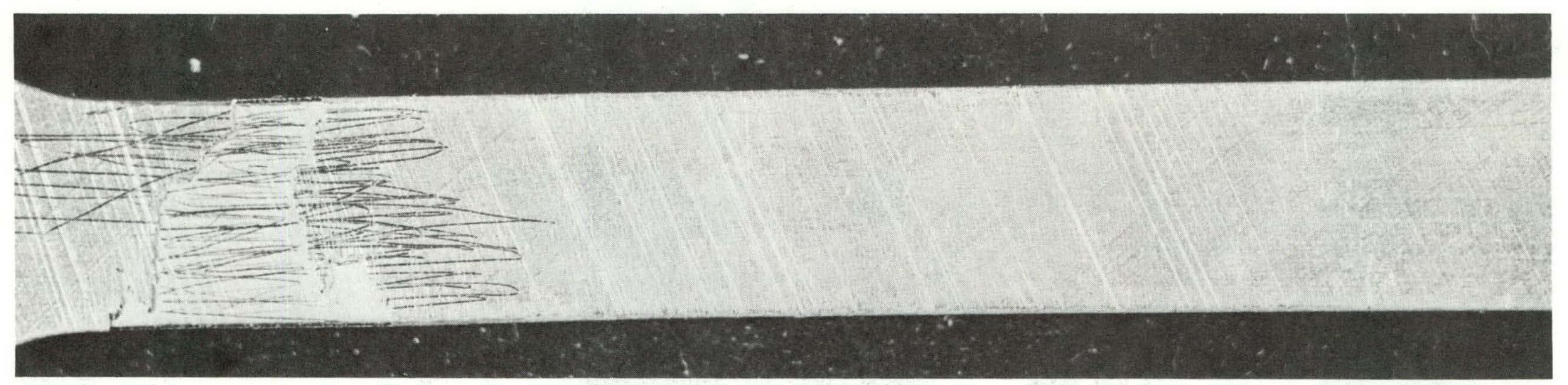

Figure 10. SPECIMEN 7807, SIDE 1, PREPARATION 2. (5X)

MS-71-0907-11

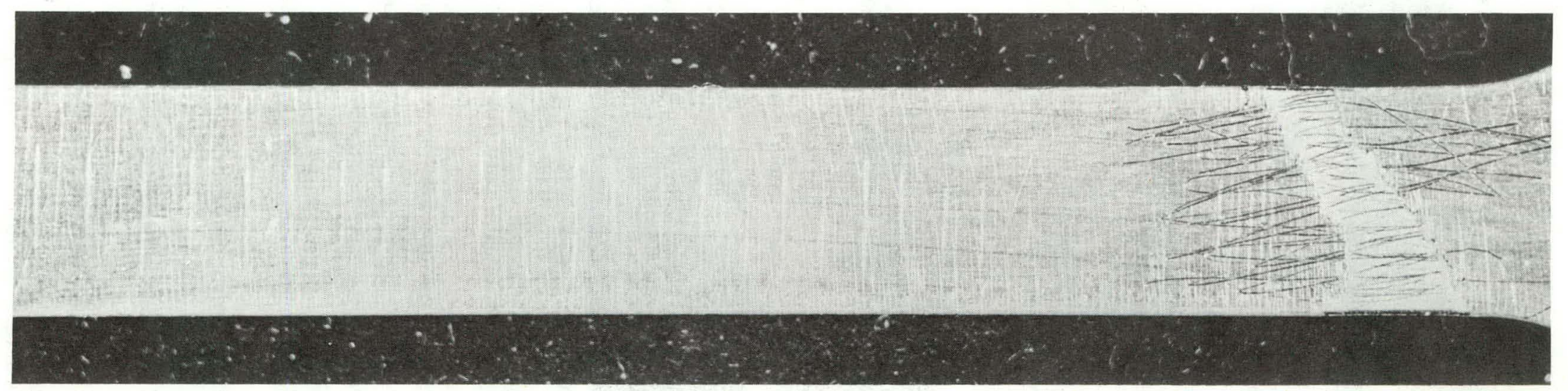

Figure 11. SPECIMEN 7807, SIDE 2. (5X)

MS-71-0907-12 


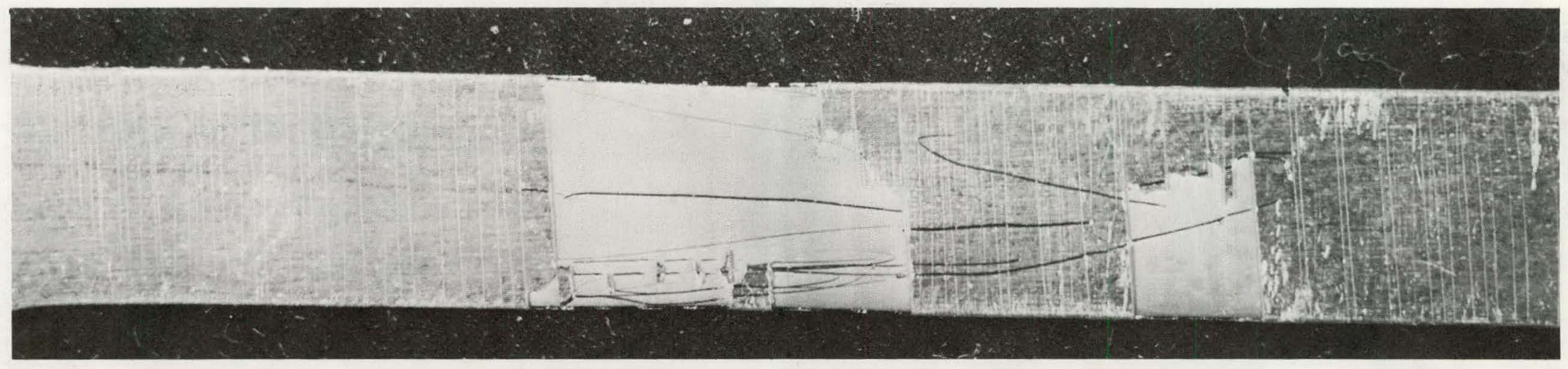

Figure 12. SPECIMEN 8007, SIDE 1, PREPARATION 4. (5X)

MS-71-0905-14

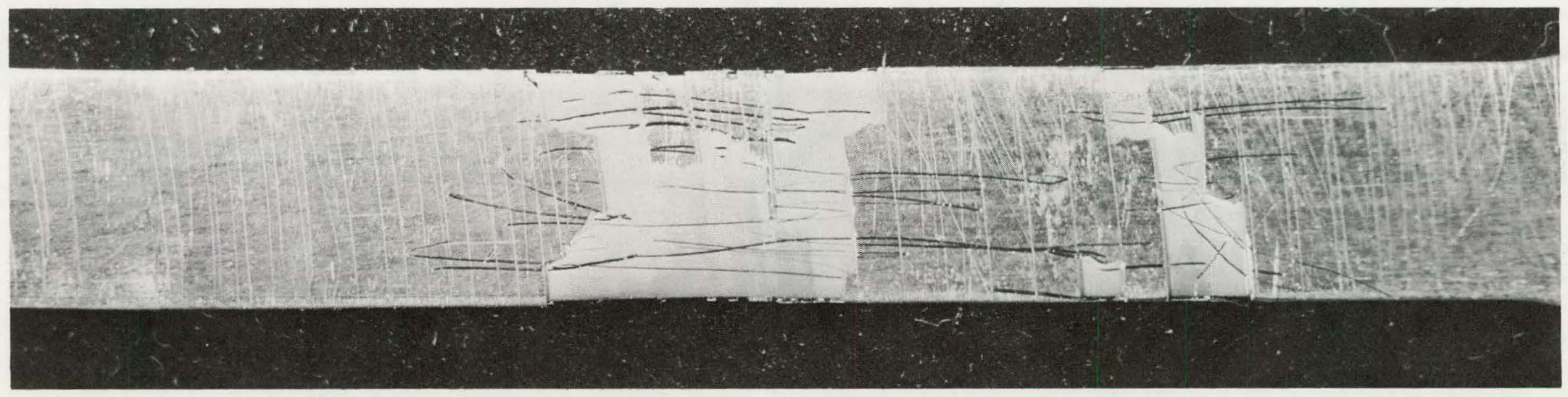

Figure 13. SPECIMEN 8007, SIDE 2. (5X)

MS-71-0905-13 


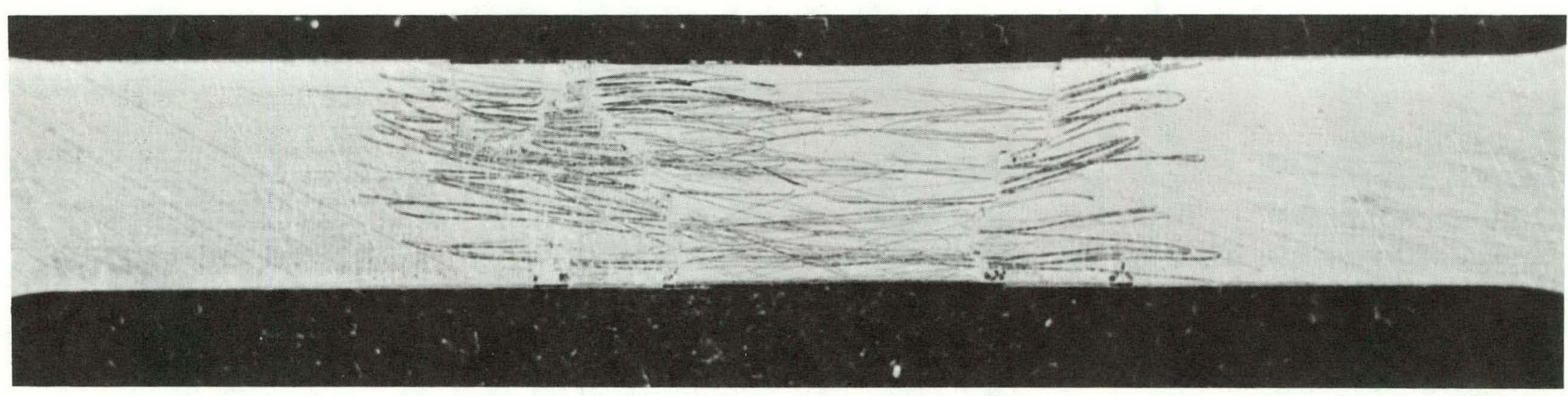

Figure 14. SPECIMEN 7809, SIDE 1, PREPARATION 2. (5X)

MS-71-0907-15

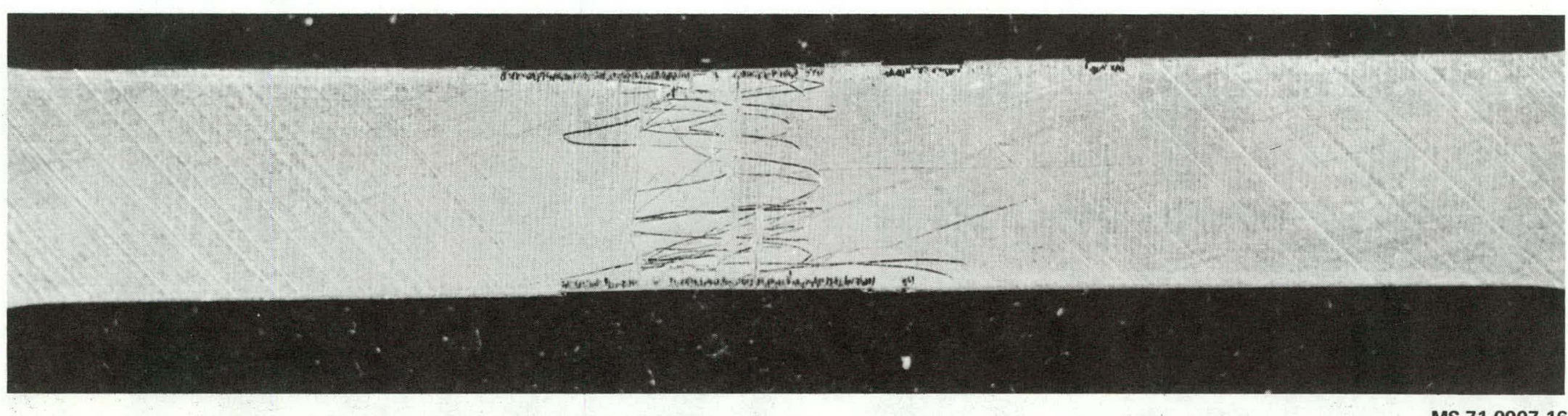

Figure 15. SPECIMEN 7809, SIDE 2. (5X)

MS-71-0907-16 


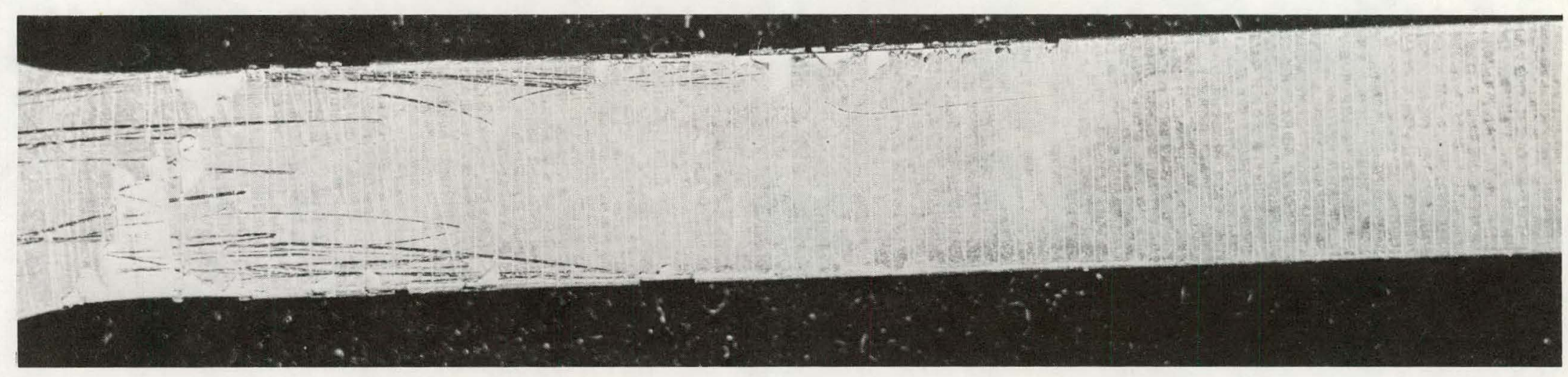

Figure 16. SPECIMEN 7223, SIDE 1, PREPARATION 1. (5X)

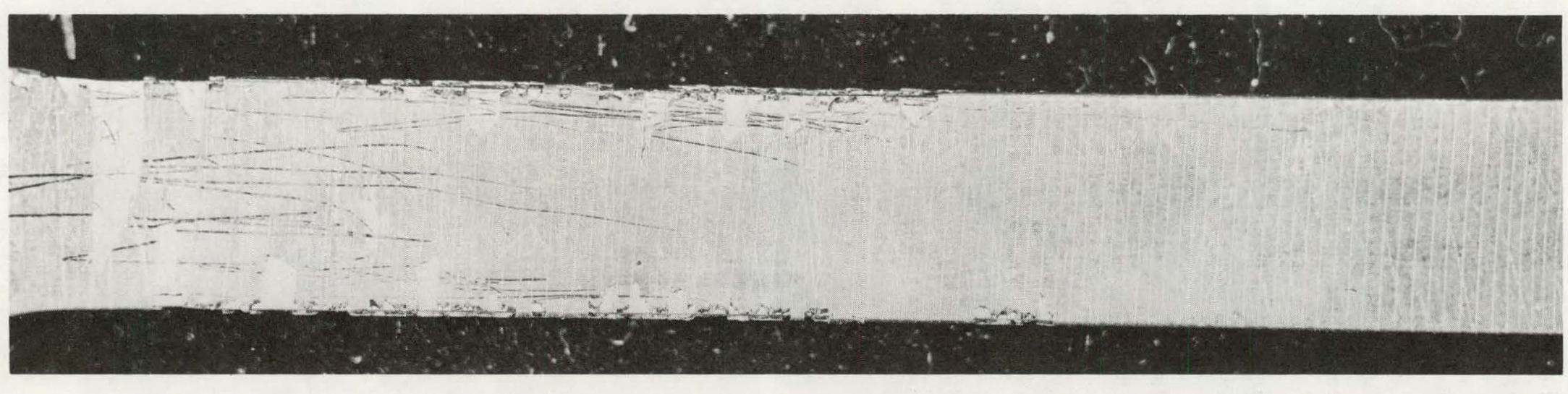


3. The four groups ranked from best to worst in surface finish are: (1) Preparation 6, (2) Preparations 4 and 5, (3) Preparations 1 and 2, and (4) Preparation 3.

\section{Crazing Lines -}

1. There is a slightly significant difference between Baths 1 and 2 for the as-machined specimens.

2. There is no apparent difference between baths for the group that was vapor blasted with 150-grit silicon oxide.

3. There is a very significant difference between those specimens that received no pretreatment and those that received any of the other treatments.

The method described herein has proven to be a reliable method for detecting adequate plating-bond adhesion, given the boundary conditions which have also been described. It is expected that it could also serve as an acceptable certification method for similar future problems where the parts in question would see service comparable to that expected of the part tested in this study. 


\section{DISTRIBUTION}

Atomic Energy Commission-ORO

Hickman, H. D.

Zachry, D. S., Jr

\section{Oak Ridge Gaseous Diffusion Plant}

Wilcox, W. J., Jr

Winkel, R. A.

\section{Oak Ridge Y-12 Plant}

Alvey, H. E.

Bernander, N. K.

Briscoe, O. W.

Burditt, R. B.

Burkhart, L. E.

Denny; A. (2)

DeRoos, L. F.

Ellingson, R. D.

Fortenbery, M. J./Edmonds, W. B.

Foulk, D. L.

Garber, J. W.

Hemphill, L. F.

Jackson, V. C.

Jones, F. W.

Kahl, K. G.

Keith, Alvin

Kite, H. T.

Knowles, C. $M$.

Long, P. J.

McLendon, J. D.

Mitchel, G. W.

Oliphant, G. W:

Patterson, H. E.

Petretzky, P. B.

Poore, M. W.

Reeves, C. A., Jr (15)
Smith, J. H.

Smith, R. D.

Smith, R. F.

Stoner, H. H.

Trebilcox, P. H.

Trotter, T. C.

Waldrop, F. B.

Weathersby, W. E.

Yaggi, W. J.

Y-12 Central Files (5)

Y-12 Central Files (master copy)

$Y-12$ Central Files (route)

$Y-12$ Central Files (Y-12RC)

Paducah Gaseous Diffusion Plant

Legeay, A. J.

Sandia-Livermore

Dini, J. W.

Scott, A. L.

In addition, this report is distributed in accordance with the category UC-37, Instruments, as given in the USAEC Standard Distribution Lists for Unclassified Scientific and Technical Reports, TID-4500. 